European nuclear power

\section{Muddle over safety measures}

A swinciline; altack on the European Economic Community (EEC)'s nuclear safety and public information record was delivered in Brussels last week by its commissioner for the environment. Stanley Clinton Davies. His remarks were apparently based on a new report from an expert committec - but those involved in the report's preparation claim it reaches wholly opposite conclusions.

The report due to be published in a few months. was drawn up by those close to the nuckear industry and it supports its policies. according to Commission sources. It is regarded. however, only as advice and the European (ommission is free to draw its own. even contradictory, conclusions.

Clinton Davies's interpretation was certainly affected by the uncoordinated response by European states to the Chernobyl nuclear disaster. which came late in the expert group's year-long deliberations. In that context the commissioner felt it necessary to eriticize the poor and late provision of public information in some countrics (by implication. France), and the very disparate actions taken in response to contamination. "Everyone got under their own umbrella". said a Commission spokesman, and some umbrellas were big and others patchy.

The environment commissioner's objective in attacking national safety measures is thus clear: he believes there is a central coordinating role to be played by the European Commission in matters of setting nuclear safety levels and the rapid collection and dissemination of information across national boundaries in the case of accidents. Thus Clinton Davies last week attacked, by implication. West Germany, Italy, the Netherlands: Belgium and others for failing to implement an EEC directive on "basic norms" for

\title{
Made in Japan label on launchers
}

Tokyo

$\mathrm{N}$ r.xi week Japan takes its first big step towards independence from US rocket technology with the test launch of its new H-I rocket.

Throughout its 17-year history, the National Space Development Agency (NASDA) has depended on licensed US rocket technology to boost its satellites into orbit. Breaking with that tradition, the $\mathrm{H}-\mathrm{I}$ has a domestically developed second-stage cryogenic engine, the LE-5. On its first test flight, a two-stage version will be flown; later flights will be of the full three-stage rocket. And, unlike its predecessors, the $\mathrm{N}$-I and N-II, the rocket will also have a new Japanese-built inertial guidance system.

Scheduled to blast off on 13 August, the $H-I$ will carry three inexpensive payloads into orbit; the Experimental Geodetic Payload (E.GP), a hollow globe over two metres in diameter, covered in mirrors and laser reflectors, that will be used by the Maritime Safety Agency and the Geographical

emissions and radiation exposure, which had been due for ratification last April. Europe's principal nuclear states, Britain and France, are not in default on "basic norms", but according to a spokesman "most" of the 12 EEC nations have failed to implement another directive, on exposure to medical $X$ rays.

Both radiation directives, agreed by the European Council of Ministers in 1984 (subject to ratification by national parliaments), are applications of the much older Euratom Treaty of 1957. This treaty is, in turn, one of the foundation stones of the European Communities and gives the European Commission wide powers to gather information and set standards of nuclear safety. The nuclear member states. in particular France, with nearly 70 per cent of its electricity demand met by nuclear power, are set firmly against such a role for the Commission. But in Brussels

\section{Soviet/West German cooperation agreed}

\section{Hamburg}

Wist Germany and the Soviet Union have agreed on closer cooperation in science and technology. Foreign Minister HansDietrich Genscher signed a framework treaty in Moscow two weeks ago which covers three sub-agreements on nuclear power, medical and agricultural research. Fifteen two-year programmes were agreed.

Then negotiations began in 1973, but soon came to a halt. Only when Chancellor Helmut Kohl met First Secretary Gorbachev in 1983 did both sides agree to continue the talks. A draft was ready in $\mathbf{1 9 8 4}$ but in the new treaty the ministers add a note of their intention to work out a fourth, additional cuph-agreement on environmentai protection.

The framework treaty is of particular importance in the light of Soviet efforts to make their nuclear power safe. The agreement includes clauses on exchange of information and scientists and the organization of meetings, exhibition and courses. Basic research may even be performed jointly in shared laboratories, but it is not yet clear what projects will be tackled. On the political side, the treaty is sure to help the progress of negotiations with East Germany on a similar treaty. Discussion began in 1973 but no agreement has been reached even after 27 meetings.
Survey Institute for laser triangulation surveys; the Japan Amateur Satellite-1 (JAS-1) for ham radio enthusiasts; and a magnetic bearing flywheel to be tested in space before incorporation into future satellites. The total budget for the launch including the satellites is 16,000 million yen (about $\$ 100$ million).

From 1988 the rocket is planned to go into regular service placing communications, broadcast, meteorological and Earth resources satellites into geosynchronous orbit. But with a maximum payload capacity of only $550 \mathrm{~kg}$, the $\mathrm{H}-\mathrm{I}$ is still small by international standards, and by 1992 NASDA hopes to replace it with the H-II, a two-stage launcher, capable of boosting a $2,000 \mathrm{~kg}$ satellite into a geostationary orbit, that will be 100 per cent "made in Japan".

Although still not in the big space league. the H-II will allow Japan to compete in the international market for the launch of small to medium scale satellites in the 1990s.

David Swinbank:

it is felt that a clear, objective, international information system is urgently needed - otherwise the European public, including even the French, will lose confidence in nuclear power altogether. Last week Clinton Davies made a firm and specific proposal that such a system be set up, although he drew back from pressing for the wider powers that the Euratom Treaty would allow, but which for the moment seem politically inopportune.

As if to confirm the commissioner's views, the influential umbrella organization for European consumer associations, the Bureau Européen des Unions des Consommateurs (BEUC), which receives a small grant from the European Commission, also recommended such an international reporting system last week. In a 35-page report which collated official and published information on national responses to the Chernobyl disaster and its fallout, BEUC contrasted, among other things, the 3,700 becquerel per litre radiation level prescribed in France in milk with the $500 \mathrm{bq} \mathrm{l}^{-1}$ upper limit in the Netherlands and Belgium, and the 20 bq $1^{-1}$ imposed during the Chernobyl affair in the German Länder of Hessen and Hamburg.

BEUC, with its large public backing through the consumer associations, also recommends in its report that the Commission adopt its full powers under the Euratom Treaty; that it set up a truly independent scientific committee to make recommendations on standards; that it prepare a European-wide contingency plan for any future accident, including one at a chemical plant; and that it develop a long-term post-Chernobyl research programme.

Robert Walgate 